\title{
Democratic legitimation of EU economic governance: challenges and opportunities for European Legislatures
}

\section{Diane Fromage \& Ton van den Brink}

To cite this article: Diane Fromage \& Ton van den Brink (2018) Democratic legitimation of EU economic governance: challenges and opportunities for European Legislatures, Journal of European Integration, 40:3, 235-248, DOI: 10.1080/07036337.2018.1450407

To link to this article: https://doi.org/10.1080/07036337.2018.1450407

(c) 2018 The Author(s). Published by Informa UK Limited, trading as Taylor \& Francis Group

册 Published online: 31 May 2018.

Submit your article to this journal

山ll Article views: 137

Q View related articles $\longleftarrow$

View Crossmark data $₫$ 


\title{
Democratic legitimation of EU economic governance: challenges and opportunities for European Legislatures
}

\author{
Diane Fromage and Ton van den Brink \\ Law Faculty, Maastricht University, Maastricht, The Netherlands
}

\begin{abstract}
This introduction sets the context of the analysis conducted in this special issue. In particular, it examines the issue of the democratic legitimacy of the European Union (EU) Economic Governance, the role of national parliaments and of the European Parliament in the European integration process. It also addresses the question of throughput legitimacy within the EU that guides all contributions. This serves as basis to study the urgency of the democratic challenge in the EU economic governance, as well as its specificity. After the contributions to this special issue are briefly presented, this introduction examines what they bring to the overall debate on democratic legitimacy in this policy domain, among others in terms of the difficulties that have arisen across Member States. At the same time, perspectives of possible future developments are also spelt out, in particular in the context of an EU-27 post Brexit.
\end{abstract}

\section{KEYWORDS}

EMU; democracy; European Parliament; national parliaments; interparliamentacy cooperation

Ten years after the outbreak of the global economic crisis, the European Union (EU) has fundamentally reshaped and reinforced its system of economic governance. The European Semester has been set up to improve budgetary and economic reform policies; the tasks of the European Central Bank (ECB) and its instruments have expanded; the Eurozone has become a clearer layer in economic governance; the European Council has appeared as the main agenda setter to initiate the major changes; the Banking Union has been created; economic reform policies are now subject to similar enforcement as budgetary policies and the European Stability Mechanism (ESM) for financial assistance to Eurozone Member States in trouble has been established. And still, despite all these reforms, we are nowhere near the completion of a comprehensive EU system of economic governance. New plans to conduct even more fundamental reforms are currently under discussion. They consist of, inter alia, creating independent EU fiscal policies and EU investment funds, a European Finance Minister and the transformation of the ESM into a European Monetary Fund (EMF) (European Commission 2017). 
The gravity of all these measures and the additional transfer of competences to the EU level induce the need for strong democratic legitimacy and democratic oversight (Cooper and Smith 2017). This has indeed been acknowledged, including by EU institutions, and national and European parliaments themselves. Most prominently, the Five Presidents Report (Juncker et al. 2015) devoted a separate section to this issue, partly on a request of the EP president. This report recognizes the need to involve both the European Parliament (EP) and national parliaments, based on the high impact of economic policies on and in the Member States. The level of abstractness and generality of that part of the report, however, remained high, especially on how to achieve better democratic legitimacy. This has been indicative for the overall struggles to increase the democratic legitimacy of economic governance.

The lack of democratic legitimacy of EU economic governance has been fiercely criticized. Most fiercely perhaps by Habermas who qualified the post-crisis system of economic governance as 'post-democratic executive federalism' (Habermas 2012). As shown by Crum (2013), while the alternative scenarios of democratic federalization and the dissolution of the Economic and Monetary Union (EMU) existed, it is the executive federalism that has prevailed in the actions taken to tackle the crisis. Democratic legitimacy should not only be strengthened to ensure democratic accountability ex post but also to guarantee ex ante input. It is indeed difficult to overestimate the democratic challenges that EU economic governance faces. At the same time, it must be admitted that notwithstanding the fact that national parliaments were not always appropriately involved in the adoption of the reform of the EU economic governance (Maatsch 2017, conclusions), parliamentary involvement has indeed been strengthened in different ways over the last years. This concerns ways to embed parliaments formally in decision-making structures, but also relates to their increased willingness and ability to engage in issues of EU economic governance. Thus, some stocktaking can be done on the effects of these recent developments. Against this backdrop, the contributions in this special issue elaborate on these improvements but also show their limitations and demonstrate where and how democratic deficits still exist. In some of the contributions, suggestions are made for improvement. This provides the basis for some reflections concerning possible future evolutions.

\section{Parliaments in EU integration}

Despite their role as primary guarantors of democratic legitimacy, national parliaments were long absent from the European integration process, both at Member State and at European level. Their role has hence been considered largely marginal (Winzen 2017, 121-150). Several reasons may account for this lack of involvement. The European parliamentary assembly today's EP - was originally composed of delegated members of national parliaments and it is only with the introduction of direct elections that this organic link between national legislatures and the European Communities was broken. The European Communities were furthermore originally constructed on the basis of a classical international Treaty. Consequently, they became part of Member States'international relations which traditionally lie in the realm of the governments' competences. The Treaties mentioned national parliaments for the first time in the Maastricht Treaty but it is only with the adoption of the Lisbon Treaty that they have been awarded a comprehensive role. Until then, they had only been mentioned in declarations and protocols and had not been attributed any specific task. By contrast, post-Lisbon national parliaments are to 'contribute actively to the good functioning of the Union' (article 12 Treaty of the EU) and have been given rights of information and 
other prerogatives to fulfil this role. Certain national parliaments subsequently became closely involved in EU affairs for the first time, and the changes observed post-Lisbon amount to a 'constitutional transformation' (Crum 2017, 822). Indeed, important discrepancies have always existed among national parliaments in their capacity and willingness to act as European(ised) actors at domestic level (see for a comparative study: Hefftler et al. 2015).

With this recognition of national parliaments as actors in the EU decision-making process, scholarly attention increased sharply (for a review of four recently published volumes see Crum 2017). Especially in the immediate aftermath of the entry into force of the new Treaty, the most popular research topic was the new power of national parliaments to control subsidiarity compliance of new legislative proposals (see inter alia Bartl 2015; Cooper 2016a; Cygan 2013; Fromage 2016a; Goldoni and Jonsson Cornell 2017; Jančić 2015, Van den Brink 2012). The relation between parliaments and governments in their capacity as representatives in the Council and the European Council has also been studied (inter alia Fromage 2017; Rozenberg and Wessels 2013) with the conclusion that shortcomings still exist in this regard. This is particularly the case because national parliaments' strengthened position as it resulted from the entry into force of the Lisbon Treaty was immediately challenged by the economic crisis. Indeed, further competences had to be transferred to the EU level to counter the crisis which resulted in an important empowerment of executive organs. Therefore, it has become even more important for national parliaments to hold their executive to account appropriately. In fact, the adoption of Eurocrisis law and the introduction of, for example, the European Semester have led to interesting changes within national parliaments as illustrated by the analyses of Buskjaer Rasmussen, Kreilinger and van den Brink in this issue. Until then, some had functioned on the basis of a European Affairs' Committee having the exclusive responsibility to deal with all EU-related topics. With the increased transfer of powers to the EU level in a domain traditionally reserved to national parliaments (power of the purse), some parliaments have now mainstreamed EU affairs among their committees, which is certainly a positive development that (finally) contributes to their Europeanization.

The EP's importance within the EU also grew over time. For long, the progressive reinforcement of the European legislature has been conceived as the solution par excellence to address the EU's democratic deficit (Barrett 2018 in this issue, Cooper and Smith 2017). As illustrated here by Fromage, likewise national parliaments, the EP was attributed some capacities to hold the EU executive to account under the newly approved Six Pack and Two Pack of legislation. Neither it nor national parliaments are however able to hold the other institutions to account fully; in particular there are no instances capable of controlling the European Council and the Council as collective organs. In a context in which the power of these institutions has largely increased, it is of utmost importance that the two levels of legislatures cooperate efficiently. This should at the very least contribute to reduce the informational asymmetry from which they both suffer vis-à-vis the executive branch. Interparliamentary cooperation in its many forms has also attracted the attention of scholars, particularly since 2009 (inter alia Crum and Fossum 2013; Fasone and Lupo 2016). These studies reveal that interparliamentary cooperation is each time more intense and take multiple forms ranging from formalized interparliamentary conferences and meetings to more ad hoc collaborations. In the economic domain, a new interparliamentary conference, the Conference on Stability, Economic Coordination and Governance, was created in 2013. Its beginnings were difficult due, among other things, to divergences as to the scope, the aim and the format of the new Conference (Cooper 2014) but it now functions normally. Whether 
it brings any added value is a question whose answer is largely dependent on the individual objectives set for this initiative. In any event, Griglio and Lupo provide here some reflections for future reforms.

\section{Broader context of EU legitimacy}

Legitimacy issues facing the EU are structural and general. Not just individual EU policies, but the EU itself as a political entity is principally contested. Euroscepticism has become a common element of political discourses, party positioning and individual attitudes. Questioning the functioning and the future of the EU has thus become a regular feature of EU integration. Neo-functionalists had argued that after a period in which EU integration would be mainly driven by elites and technocrats, ultimately the wider public would be drawn into the European political arena and a process of identification with the EU would emerge, based on the positive results of EU integration (Hooghe and Marks 2006). The increased politicization of the EU - which was seen a necessary step in that process - has indeed emerged, but not in the way foreseen. And it has not led to increased support and identification with the EU, although the overall support for EU integration remains at generally high levels. ${ }^{1}$

Some of the EU's individual policies are equally increasingly contested. The EU has gained powers in politically sensitive domains which affect Member States' sovereignty, such as Justice and Home Affairs matters. Also, as the current revision of the Posted workers directive is demonstrating, EU actions based on existing powers are increasingly contested as well.

The EU has a volatile constitution as could be expected given that it was originally conceived as a 'classical' international organization and as it has only gradually evolved towards a sui generis entity. It constantly changes, and not only on minor points. Addressing legitimacy issues has accounted for some of these changes. Over the course of time, the democratic foundations of decision-making have been reinforced, since the 1970s focusing primarily on strengthening the EP as mentioned before. The European legislature progressively gained power until it became co-legislator in almost all domains. Arguably the Treaty of Lisbon has marked the most significant next step in this regard. It made the democratic model of the EU explicit for the first time. The Treaty provides that the EU is based on representative democracy (art. 10 TEU). Next to the EP, the Treaty acknowledges national parliaments as key actors in this domain as they are in charge of holding to account their national representatives sitting in the Council. The principle according to which democratic legitimacy is to be ensured at the level at which a given decision is taken, i.e. the EP is the prime and sole responsible of the democratic legitimacy of EU institutions' decisions, is however strongly anchored, even in areas where not all Member States participate thereby setting the EP in a more dubious position (in the Four Presidents' Report the principle that accountability should follow the level of decision-making has been laid down as the key principle as well: van Rompuy et al. 2012 and Van den Brink 2012, 16). Furthermore, despite this, as noted above, the EP's oversight capacity over the Council and the European Council are, in reality, very weak so that these institutions remain de facto outside the realm of parliamentary oversight. Representative democracy is, however, not the exclusive legitimacy basis of the EU as the Treaty also includes elements of participatory democracy (most notably consultation requirements) and direct democracy (the Citizens' Initiative). Other legitimacy strands have been strengthened over the years too, such as the possibilities for judicial review and the introduction of the EU Charter of Fundamental rights. 
Despite the existence of all these democratic channels, EU citizens still perceive the EU as undemocratic and overly technocratic. Even the Citizens' initiative - which is the citizens' primary means of direct involvement - has shown limitations in its functioning and is currently being reformed. ${ }^{2}$

The EU's continuous constitutionalization process has also produced its own legitimacy issues. The need for the EU to be able to address political, economic and societal challenges has resulted in a continuous expansion of its powers. This has created tensions as the risk of competence creep and integration by stealth have negative effects on the legitimacy of the EU. Attempts to address the competence issue have included a better delineation of EU powers and a more rigorous application of subsidiarity through the Lisbon Treaty (on the competence creep and the attempt at better defining EU competences: Weatherhill 2004). The current Better Lawmaking policy equally includes explicit elements that help to limit EU action. ${ }^{3}$ The rise of executive power in the EU without adequate democratic control mechanisms has also been the subject of attention. New methods of EU governance, including the increased position of EU agencies, have raised questions of democratic legitimacy and accountability (Curtin 2005). Thus, the EU's continuous constitutionalization process addressed some legitimacy issues, but created new ones too.

The EMU, and economic governance more broadly, is part of that same ambiguous constitutionalization process that both triggers and addresses legitimacy issues. The strengthening of economic governance has intensified the calls for appropriate democratic control. The fact that numerous decisions, such as the creation of the ESM and the actual granting of financial assistance under its scheme, but also the Treaty on Stability, Coordination and Governance (TSCG), have all been emergency measures is a complicating factor in this regard. But to some extent, EU economic governance now also includes mechanisms to foster democratic accountability and legitimacy. Some of these mechanisms arose in practice first and have gradually developed into'harder' and institutionalized forms of democratic control and accountability.

Three avenues have been pursued to strengthen democratic legitimacy of economic governance. These avenues had already been explored in the context of general EU policies and are now also applied in this field. The first one entails a strengthening of the position and powers of the EP. The Economic Dialogue and the Monetary Dialogue are among the main examples of the initiatives taken with this aim. The second avenue regards reinforcing the position of national parliaments. Their budgetary rights have been affected by EU economic governance and ways have been sought to compensate for this disempowerment. Lastly, mechanisms to create and stimulate interparliamentary cooperation have been created as previously mentioned.

\section{Reinforcing throughput legitimacy: The urgency of the democratic challenge in EU economic governance}

EU economic governance raises important questions and issues of throughput legitimacy. In this special issue, these questions and issues are identified and analyzed, alongside the ways that have already been developed - or should in the future be developed - to address these matters. Clearly, other legitimacy concerns exist as well, most notably in relation to whether EU economic governance delivers the results it envisages (see e.g. Alcidi and Gros 2015). Throughput legitimacy of EU economic governance, however, requires special and 
in-depth attention. The throughput legitimacy perspective essentially zooms in on the legitimacy of decision-making processes and mechanisms. It examines the accountability, transparency, and efficacy of such processes along with their openness to pluralist consultation with the people (Schmidt 2013). This approach therefore views how the various actors involved - in this case in EU economic governance - interact (Schmidt 2013). Such an approach is strongly needed for EU economic governance considering its features recalled above.

Democratic legitimacy of EU economic governance is particularly urgent, despite the existing and newly created mechanisms to secure it. Firstly, the EU's 'constitution' for economic governance has proved particularly volatile in the last decade. The institutional architecture of the EU's economic governance has changed significantly over the past ten years and is now based on a wide variety of measures and practices. Some of them are legislative, most notably the so-called Six Pack (2011) and Two Pack (2013) of legislation. Others were adopted in the form of international treaties. The ESM and the TSCG are the paradigmatic examples of Member States' resort to international law. The Treaty of Lisbon made some changes to economic governance as well, most notably to the role of the ECB. If we take a broader approach to economic governance, the Banking Union should indeed be included too. This is now a regulatory system, mainly built through EU secondary legislation but it also includes an international treaty regulating the contributions to the Single Resolution Fund (SRF). The adoption of all these measures and the way they interrelate raise issues of democratic legitimacy. Key questions regard the capacity and the actual behaviour of the EP and of national parliaments to hold executive actors to account and to scrutinize economic decision-making. The capacity of parliaments to increase throughput legitimacy includes formal aspects, such as the legal powers they possess, but also openness of decision-making processes and supply of information.

The complexity of current EU economic governance is the second reason why the throughput perspective is key. The system is so complex because it intricately combines 'harder' and 'softer' elements as well as European and national modes of decision-making (see Section 5). Moreover, EU economic governance balances political and non-political (technocratic; rules-based) decision-making, with the political aspects gradually becoming stronger. Illustrative in this regard is the Stability and Growth Pact (SGP) that has traditionally been firmly rules-based. However, during the economic crisis, various Member States were faced with difficulties to comply with the rules and this has required the Commission to consider in which circumstances and under what conditions the Member States could be allowed to - temporarily - exceed the norms. This entailed a certain margin of appreciation for the Commission, and thus created room for political decision-making. Also, the Commission's decision to attach more weight to the public debt criterion has essentially been a political decision. Lastly, the strengthening of EU economic reform policies and policies to address and prevent macroeconomic imbalances has equally strengthened the political dimension of EU economic governance (see in particular Van den Brink in this issue).

The third reason why throughput legitimacy of EU economic governance is a key issue concerns the future development of EU economic governance. Although the economic situation in certain Member States (including bigger ones such as France and Italy) is still cause for serious concerns, European economies have, generally, reached quieter waters. Apparently following the advice to mend the roof while it is not raining, plans have been presented to reform the EU's economic governance in a more fundamental way. Following 
a general Reflection paper (June 2017), the Commission presented a package of proposals in December 2017 to reform EU economic governance. A strong driver behind these proposals (several contributions in this issue discuss them more elaborately) is the need to make economic governance more effective. If these were adopted, the position of the decision-making actors would change significantly and thereby the possibilities and need for parliaments to be involved as well.

The throughput perspective on EU economic governance is certainly not new, but this special issue seeks to offer a more comprehensive assessment of the issues involved and the ways to address them. This assessment first pursues to combine arguments based on the system as it has been developed with arguments regarding the way in which this system functions in practice. Second, the throughput perspective is applied to EU economic governance in general, thus including not only the European Semester, but for instance also the Banking Union and the role of the ECB therein. Lastly, the contributions of this special issue consider national parliaments, the European Parliament and interparliamentary cooperation as potential suitable avenues to strengthen throughput legitimacy of EU economic governance.

\section{The specificity of the democratic challenge in EU economic governance}

Compared to EU decision-making in general, the role of parliaments is very different in economic governance. There are several reasons for this. First, the complex legal framework as elaborated above has created an intricate and largely self-standing decision-making system. The relation between national and EU powers is not always clear especially in the field of budgetary and economic reform policies. In the words of Armstrong (2013), the current system is a combination of coordination-based and supranational forms of cooperation. This is aggravated by the interplay between the EU and the international law framework. Especially the relation between EU norms and the TSCG is complex. This complicates in particular for national parliaments the way in which they may be involved in the decision-making and their choice on which norm to focus. This may also lead to difficulties in determining which parliaments (national or European) are better placed to ensure democratic legitimacy.

Second, not only the legal framework is distinct in economic governance, but also the very nature of the decision-making differs. In many fields of EU policy, the role of the EU is mostly limited to legislating, or, more generally adopting general rule-making acts (including secondary legislation partly based on comitology). As implementation and enforcement are usually left to the Member States, executive decision-making is less common. In EU economic governance the situation is in fact the opposite. Whereas legislation does not play a key role (apart, perhaps, from the Banking Union), executive decision-making is the way in which economic governance is shaped par excellence. This is true for the actions of the ECB, for decision-making on bailouts but also for decision-making in the European Semester and within the mechanisms of enhanced surveillance (such as the Excessive Deficit Procedure and the Excessive Imbalances Procedure). This makes it problematic for parliaments to simply rely on the role and the powers they have acquired regarding legislative procedures (i.e. the EP's co-legislative role and national parliaments' involvement in the EU legislative process).

The inability to rely on existing mechanisms of parliamentary involvement has resulted in a third factor that defines the specificity of the democratic challenge in EU economic 
governance: the specific means of parliamentary involvement that have already been created. These may be indeed new, or customized to fit economic governance (such as interparliamentary cooperation). And they may be formal (such as the right of national parliaments to invite the responsible Commissioner to discuss Country Specific Recommendations) or informal (such as the possibility for the EP to amend legislative proposals from the Six Pack even if it lacked the formal power to do so). Even though it may still be immature and far from complete - and many authors in this special issue supply compelling arguments why this is indeed so - some type of democratic arena in EU economic governance is indeed emerging.

Other factors which contribute to the specific nature of the democratic challenge have partly been discussed in the preceding sections already and may thus only be briefly mentioned here. They include: the fact that considerable parts of economic governance involve the adoption of urgency measures; the complication related to the fact that part of the decision-making process takes place at the level of the Eurozone rather than of the EU-28; and lastly the de-politicized nature of some of the key substantive norms. This latter factor may indeed question the desirability of parliamentary involvement.

\section{Introducing the contributions}

The articles of this special issue comprehensively reexamine the democratic (throughput) legitimacy of, and within, the EU's economic governance. They do so by focusing on national parliaments, on the EP and on mechanisms for interparliamentary cooperation. Economic governance is viewed in a comprehensive sense, covering a wide range of policies. It includes the role of parliaments in core aspects of the EMU, such as the European Semester. The challenges of the democratic legitimacy of EU monetary policy and the accountability of the ECB are addressed as well. But this special issue also covers areas outside of the strict confines of the EMU, such as the Banking Union, since it is key to guaranteeing financial stability and the continued existence of the common currency. Another subject addressed in this issue that falls outside the scope of the EMU but indeed relates to economic governance as well concerns the EU budget. Although the constitutional framework of the EU makes a sharp distinction between the coordination of national budgetary policies (part of the EMU) and the EU budget (not part of the EMU), there are obvious links between the two in practice, not least because they are strongly intertwined and influenced by one another. EU economic governance has, furthermore, some specific features which impact the role of parliaments. Some parts of economic governance are not based on EU law, but rather on international treaties, such as the ESM Treaty and the TSCG. Another specific feature concerns the status of the Eurozone. Although this status is largely informal, it has in fact grown into a separate layer of governance inter alia with the formalization of Eurozone-specific political arenas, such as the Euro summits. This evolution has sparked calls for corresponding democratic legitimacy, i.e. for the establishment of parliamentary instances that mirror the composition of the newly created executive bodies. A third specific feature of EU economic governance regards the fact that decisions are (and have been) sometimes taken under great time pressure. This is inter alia the case with regard to the rescue packages under the ESM. Such urgency decision-making brings along its own issues of democratic legitimacy.

In addressing all these questions, this special issue effectively builds upon and complements the existing literature. It delves into the question of how exactly scrutiny is performed 
and thereby confirms previous studies (Crum 2018; Hallerberg, Marzinotto, and Wolff 2018; Kreilinger 2016) in which national parliaments' attempts to develop ownership over the European Semester procedures was analysed by showing that, even after the seventh cycle of economic coordination, important shortcomings and differences among parliaments remain that may eventually be linked to the individual situation of the Member State at stake. The analysis offered in this special issue also complements previous findings on the ECB's accountability in the monetary domain (inter alia Amtenbrink and van Duin 2009; Jančić 2017) by adding the new dimension of the Banking Union and by contemplating both national and European Parliaments (Amtenbrink and Markakis 2017). It brings a fresh look on the potential of interparliamentary cooperation in the economic and monetary domain taken at large, and in the framework of the Interparliamentary Conference on Stability, Economic Coordination and Governance in particular, coming to the same conclusion that, as previous studies have found (Cooper 2016b; Fromage 2016b), some issues still exist almost five years after its creation.

In the first contribution, Barrett takes a broad perspective on the democratic legitimacy of EU economic governance by assessing the roles of the EP and national parliaments and by considering both economic and monetary policies. He contends that, although some improvements have been introduced with regard to national and European legislatures, in practice not all the proposals formulated have effectively been implemented and that hence more still needs to be done to ensure sufficient democratic accountability in EMU.

Following this introductory contribution, a set of three contributions follows that focus on the EU level and the EP, and its intertwinement with the national level. Fasone examines the questions of the intertwinement between the EU and national budgets and the role the EP and national parliaments can play in this regard to ensure democratic legitimacy. It is argued, first, that decision-making on the EU budget and coordination of national budgetary policies should be better aligned. Second to ensure smooth cooperation, 'interparliamentarism by committee' should be resorted to.

Fromage subsequently analyzes the role of the EP in the EMU. She elaborates on the ways in which the EP has been empowered following the adoption of Eurocrisis law and assesses the potential impact of the reform proposals made by the Commission in its December 2017 package. This article highlights that the EP now has three instruments at its disposal: control mechanisms designed around Euro summits; the possibility to hold an Economic Dialogue and the participation in interparliamentary cooperation. Formally, it may, thus, seem that the EP has acquired strong participation powers. Practice shows nonetheless that in reality its empowerment has remained fairly limited. Hence, the EP could make a more intensive use of its rights and further reforms could be implemented.

Fromage and Ibrido then focus on a particular element of the EP's control powers, the Monetary Dialogue. The central question this contribution addresses is whether the Monetary Dialogue, which has long existed between the EP and the ECB, could be reformed following the model newly established by the Banking Dialogue created in the Banking Union. In particular, this contribution argues that one of the ways to reform the Monetary Dialogue could be to involve national parliaments. A reform of the Monetary Dialogue could enhance its potential, in general and for the EP specifically. Such an evolution would eventually contribute to enhance the ECB's, and the EU's at large, democratic legitimacy.

The next set of articles is specifically devoted to national parliaments' participation. Van den Brink examines how national parliaments are involved in economic performance policies 
(macroeconomic and economic reform policies), one of the pillars of the EMU that has arguably changed most drastically because of the adoption of Eurocrisis law. Based on an analysis of the policy dialogues with Germany, France, the United Kingdom and the Netherlands, he concludes, that although the legal framework has indeed changed considerably, the level of involvement of parliament depends on the actual impact of EU economic performance policies on the Member States in question. Hence, while the potential impact of economic performance policies is substantial, in practice differences across Member States are significant, and parliamentary involvement varies largely. Consequently, it is contended that it would be difficult to establish one single model of parliamentary involvement in this domain.

Buskjaer Rasmussen identifies three policy-making modes in national parliaments' participation in the European Semester. In looking at the Danish, the Swedish and the Spanish parliaments, she shows that differences exist - to the detriment of parliaments - between parliamentary involvement in this field and in the ordinary legislative procedure. Variations in the individual parliamentary practices also surface from the analysis of the usage of these prerogatives in practice, in a similar fashion as in the Member States contemplated by van den Brink.

Kreilinger then adds to this analysis by examining another set of four parliaments - France, Germany, Ireland and Portugal - to determine what factors trigger parliamentary involvement, in particular because it does not only vary across states but also over time being different from one cycle to the other. He concludes that parliamentary involvement in the European Semester is not comprehensive, and that while parliamentary powers in EU affairs and budgetary matters are a precondition for efficient involvement, they do not suffice.

Griglio and Lupo zoom in on the third focus of this special issue: interparliamentary cooperation. They examine how the newly started cooperation between European and national legislatures in the framework of the interparliamentary conference on Stability, Economic Coordination and Governance may remedy the impossibility for either national parliaments or the EP to control EU executive instances adequately by enhancing their respective knowledge. This article highlights that it has so far not been a greatly successful initiative but that the existing limitations could be overcome by a change of perspective, thereby underlining the potential of interparliamentary cooperation in general also pointed at by Fasone.

\section{Taking stock and looking ahead}

The contributions included in this special issue thus illustrate that the capacities of both the European Parliament and national parliaments to participate in EMU have been undoubtedly reinforced in different domains as well as in the closely related Banking Union. At the same time, many of the contributions argue that there is still potential for further improvements as these new prerogatives are yet to be exploited fully. This would be necessary to compensate the tendencies towards executive federalism that have grown since the economic crisis started.

A better use of existing prerogatives and possibilities of involvement may, however, not suffice to correct this tendency, and to ensure democratic legitimacy. It is indeed questionable whether this would suffice to compensate the existing imbalance between executive power and democratic control in EU economic governance. Further reaching proposals have already been tabled inter alia in the Commission's recent Reflection paper and EMU Reform package, and they are in part also addressed in this special issue. 
Even if the EMU is incomplete and requires further reforms, the contributions contained in this special issue allow taking stock of the role of parliaments in EU economic governance, while this role is still being defined. Indeed, it may not be farfetched to assume that parliaments will not find definite forms of involvement in many years to come because of future reforms at EU level and because of the currently incomplete use of the existing mechanisms. The experiences with the role of national parliaments and the European Parliament in EU legislative procedures may be telling in this regard while further conceptual, normative and empirical questions are deemed to arise as new steps are taken.

The current state of affairs within the EU will inevitably lead to changes in the domains addressed in this special issue, not least because of Brexit. Brexit is indeed both a threat and an opportunity for the EU-27. In terms of the EU budget for instance, the withdrawal of the United Kingdom (UK) will demand from the remaining Member States that they find new resources to fill in the gap created by this exit. At the same time, this need for reform could allow Member States to find solutions to problems that have exited for long in relation to rebates or to the limited own resources. ${ }^{4}$ In fact, the European Commission has launched a new debate on the future of EU finances and it can only be hoped that the interplay between Member States and the EU, and their parliaments, will be improved.The UK's exit from the EU could represent an opportunity for the EMU more generally as well. The complex architecture of EU economic governance with, for instance, the co-existence of instruments of EU and international law is, at least in part, a consequence of the UK's opposition to Treaty revisions. In this sense, its exit from the EU makes the protection of the integrity of EU law a reachable objective if Member States so wish.

Also, the balance between Eurozone and non-Eurozone Member States will shift. Not only is the non-Eurozone block losing one of its members but it is also losing a large and economically powerful one that had been strongly advocating the interests of non-Eurozone states. ${ }^{5}$ In this context, the Commission has voiced its support for more'unity' among Member States and non-Eurozone States could become even less numerous in the near future.

In parallel to the Brexit debate, the more general question of the future of the EU as a whole has come in the limelight. The European Commission presented a White paper on this topic in Spring 2017 (European Commission 2017), and in particular one of the scenarios it featured could have implications for democratic legitimacy and the role of parliaments. Should the possibility for '[t]hose who want more do more' (20) move forward (i.e. more differentiated integration), this would eventually mean that the tensions in the EP's role as the organ in charge of ensuring representative democracy could increase even further. Such an evolution would indeed most probably happen naturally as the EP, as it exists now, cannot represent the interests of the Eurozone only. The role of national parliaments too would become increasingly complex and more difficult than it already is because the gap between Eurozone and non-Eurozone Member States would widen further which would make the design of one single model for parliamentary involvement even more difficult. It would bring to the fore the dilemma that exists between the tendency to exclude non-Eurozone parliaments and the necessity to involve them because their Member States may still be affected by the decisions taken within the Eurozone. The Commission appears to have moved away from this scenario in its 2017 State of the Union speech, but this does not imply that (some) Member States will not continue to push in that direction.

For any reform to succeed however, a certain consensus among Member States must emerge. This is particularly the case if Treaty changes are to be implemented. But even the 
adoption of measures in the form of an international Treaty demand that at least a number of Member States agree. Even if it is too early to make any final prognosis, the latest results of the Dutch and the French elections have surely brought about some hope and shown that the rise in citizens' Euroscepticism cannot be simply overturned. To try and make this tendency last over time, the roles assumed by national and European legislatures should be clarified and reinforced to compensate the emergence of executive organs and the imbalance of powers in their favour. This is particularly needed because EMU and the Banking Union affect core prerogatives of parliaments. For this very reason, national parliaments especially should be better involved in the procedures currently existing, and in those that would result from the reinforcement of the structures in place. Whereas a large part of the decisions now taken at EU level in the economic and monetary domain are directly tailored to individual Member States, their national parliaments are only marginally involved in their design, or at least they are not equally participating and rely on the rights attributed to them at national level. To achieve these goals, some of the obstacles for better (national) parliamentary involvement identified by the contributions contained in this special issue should be overcome. They include, for instance: the lack of formal powers, timing issues, lack of clarity and transparency of decision-making organs such as the ECB or the Euro summits, insufficient information, an absence of interest on the side of MPs or their insufficient expertise, and the difficulty to properly identify the impact of certain recommendations. What the articles of this special issue have also shown however is that none of these obstacles is unsurmountable. One way for national parliaments to remedy these issues is also closer interparliamentary cooperation as it could help fill in the informational gap. By contrast, it appears difficult to imagine how the interparliamentary conference on Stability, Economic Coordination and Governance could provide the arena for anything that would go beyond such exchange of information. A second parliamentary chamber could be more suited to ensure adequate accountability.

This debate is all the more important as the contributions undoubtedly show that accountability of executives is indeed a key issue at present, perhaps more so than the actual influence on the content of the policies. Or perhaps accountability is a necessary first step before parliaments can play a true role in shaping decisions.

\section{Notes}

1. Standard Eurobarometers http://ec.europa.eu/commfrontoffice/publicopinion/index.cfm/ Survey/index\#p=1\&instruments=STANDARD.

2. European Commission,'Public consultation on the European citizens' initiative'http://ec.europa. eu/info/consultations/public-consultation-european-citizens-initiative_en.

3. Interinstitutional Agreement between the European Parliament, the Council of the European Union and the European Commission on Better Law-Making of 13 April 2016.

4. On the reform of the EU budget: High level group on own resources 2016.

5. This was visible in the 'Decision of the heads of state or government, meeting within the European Council, concerning a new settlement for the United Kingdom within the European Union' adopted by the European Council on 19 February 2016.

\section{Disclosure statement}

No potential conflict of interest was reported by the authors. 


\section{References}

Alcidi, C., and D. Gros. 2015. "Economic Policy Coordination in the Euro Area under the European Semester." CEPS Special Reports, nr. 123.

Amtenbrink, F., and M. Markakis. 2017. "Towards a Meaningful Prudential Supervision Dialogue in the Euro Area? A Study of the Interaction Between the European Parliament and the European Central Bank in the Single Supervisory Mechanism." ADEMU, Working Paper 2017/079.

Amtenbrink, F., and K. van Duin. 2009. "The European Central Bank before the European Parliament: Theory and Practice After Ten Years of Monetary Dialogue." European Law Review 34 (4): 561-583.

Armstrong, K. 2013. "The New Governance of EU Fiscal Discipline." European Law Review 38 (5): 601-617.

Barrett, G. 2018. "European Economic Governance: Deficient in Democratic Legitimacy?" Journal of European Integration.

Bartl, M. 2015. “The Way We Do Europe: Subsidiarity and the Substantive Democratic Deficit." European Law Journal 21 (1): 23-43.

Buskjær Rasmussen M. 2018. "Accountability challenges in EU economic governance? Parliamentary scrutiny of the European Semester" Journal of European Integration.

Cooper, I. 2014. "Parliamentary Oversight of the EU after the Crisis: On the Creation of the 'Article 13 ' Interparliamentary Conference" LUISS Guido Carli School of Government Working Paper No. SOGWP21/2014.

Cooper, I. 2016a. "Is the Subsidiarity Early Warning Mechanism a Legal or a Political Procedure? Three Questions and a Typology" RSCAS EUI Working paper 2016/18.

Cooper, I. 2016b. "Interparliamentary Conference on Stability, Economic Coordination and Governance in the European Union the 'Article 13 Conference')." In Lupo and Fasone, eds. Interparliamentary Cooperation in the Composite European Constitution. Oxford: Hart Publishing.

Cooper, I., and J. Smith. 2017. "Governance Without Democracy? Analysing the Role of Parliaments in European Economic Governance After the Crisis - Conclusions." Parliamentary Affairs 70 (4): 645-654.

Crum, B. 2013. "Saving the Euro at the Cost of Democracy?" Journal of Common Market Studies 51 (4): 614-630.

Crum, B. 2017. National Parliaments and Constitutional Transformation in the EU. European Constitutional Law Review 13 (4): 817-835.

Crum, B. 2018. "Parliamentary Accountability in Multilevel Governance: What Role for Parliaments in Post-crisis EU Economic Governance?" Journal of European Public Policy 25 (2): 268-286. doi:10.108 $0 / 13501763.2017 .1363270$.

Crum, B., and J. E. Fossum, eds. 2013. Practices of Inter-Parliamentary Coordination in International Politics. The European Union and Beyond. Essex: ECPR.

Curtin, D. 2005. "Delegation to EU Non-majoritarian Agencies and Emerging Practices of Public Accountability." In Regulation Through Agencies: A New Paradigm of European Governance, edited by D. Geradin and N. Petit, 88-119. Cheltenham: Edward Elgar.

Cygan, A. 2013. Accountability, Parliamentarism and Transparency in the EU: The Role of National Parliaments. Cheltenham: Edward Elgar.

European Commission. 2017. Reflection Paper on the Deepening of the Economic and Monetary Union. $\operatorname{COM}(2017) 291$ final.

Fasone, C. 2018. "Towards a Strengthened Coordination Between the EU and National Budgets. A Complementary Role and a Joint Control for Parliaments?" Journal of European Integration.

Fasone, C., and N. Lupo, eds. 2016. Interparliamentary Cooperation in the Composite European Constitution. Oxford: Hart.

Fromage, D. 2016a. "The Second Yellow Card on the EPPO Proposal: An Encouraging Development for Member State Parliaments?" Yearbook of European Law 35 (1): 5-27.

Fromage, D. 2016b. "European Economic Governance and Parliamentary Involvement: Some Shortcomings of the Article 13 Conference and a Solution." Le Cahiers européens de Sciences Po. http:// www.sciencespo.fr/centre-etudes-europeennes/sites/sciencespo.fr.centre-etudes-europeennes/ files/201601_fromage.pdf.

Fromage, D. 2017. "Executive Accountability to National Parliaments in Post-Crisis EU Affairs: The Persistent Shortcomings in the Council and the European Council Oversight." In National Parliaments 
after the Lisbon Treaty and the Euro crisis: Resilience or Resignation?, edited by Davor Jančić, 159-175. Oxford: Oxford University Press.

Fromage, D. 2018. “The European Parliament in the Post-crisis era: An Institution Empowered on Paper Only?" Journal of European Integration.

Fromage, D., and R. Ibrido. 2018. "The 'Banking Dialogue' as a Model to Improve Parliamentary Involvement in the Monetary Dialogue?" Journal of European Integration.

Goldoni, M., and A. Jonsson Cornell. 2017. National and Regional Parliaments in the EU-Legislative Procedure Post-Lisbon: The Impact of the Early Warning Mechanism. Oxford: Hart.

Griglio, E., and N. Lupo. 2018. "The Conference on Stability, Economic Coordination and Governance: Filling the Gaps of Parliamentary Oversight in the EU." Journal of European Integration.

Habermas, J. 2012. The Crisis of the European Union: A Response. Cambridge: Polity Press.

Hallerberg, Mark, Benedicta Marzinotto, and Guntram B. Wolff. 2018. “Explaining the Evolving Role of National Parliaments Under the European Semester." Journal of European Public Policy 25 (2):250-267. doi:10.1080/13501763.2017.1363273.

Hefftler, C., Neuhold, C., Rozenberg, O., Smith, J. (ed.) 2015. The Palgrave Handbook of National Parliaments and the European Union. Basingstoke: Palgrave.

High Level Group on Own Resources. 2016. Final Report and Recommendations of the High Level Group on Own Resources.

Hooghe, L., and R. Marks. 2006. "The Neofunctionalists were (Almost) Right: Politicization and European Integration." In The Diversity of Democracy: Corporatism, Social Order and Political Conflict, edited by Colin Crouch and Wolfgang Streeck, 205-222. Cheltenham: Edward Elgar.

Jančić, D. 2015. "The Game of Cards: National Parliaments in the EU and the Future of the Early Warning Mechanism and the Political Dialogue." Common Market Law Review 52 (4): 939-976.

Jančić, D. 2017. "Accountability of the European Central Bank in a Deepening Economic and Monetary Union." In National Parliaments after the Lisbon Treaty and the Euro Crisis: Resilience or Resignation?, edited by D. Jančić, 141-158. Oxford: Oxford University Press.

Juncker, J.-Cl., et al. 2015. The Five Presidents' Report: Completing Europe's Economic and Monetary Union. https://ec.europa.eu/commission/sites/beta-political/files/5-presidents-report_en.pdf.

Kreilinger, V. 2016. National Parliaments, Surveillance Mechanisms and Ownership in the Euro Area. Vol. $n^{\circ} 110$, Studies and Reports. Berlin: Jacques Delors Institut.

Kreilinger, V. 2018. "Normal and Exceptional Activities of National Parliaments in EU Economic Governance." Journal of European Integration.

Maatsch, A. 2017. Parliaments and the Economic Governance of the European Union. Talking Shops or Deliberative Bodies?. London: Routledge.

Rozenberg, O., and W.Wessels (coord.). 2013. “Democratic Control in the Member States of the European Council and the Euro zone Summits." Study for the EP AFCO Committee PE 474: 392.

Schmidt, V. A. 2013. "Democracy and Legitimacy in the European Union Revisited: Input, Output and Throughput." Political Studies 61 (1): 2-22.

Van den Brink, T. 2012."The Substance of Subsidiarity. The Interpretation and Meaning of the Principle after Lisbon." In The Treaty of Lisbon and the Future of EU Law and Policy, edited by M. Trybus and L. Rubini, 160-178. Birmingham, AL: Edward Elgar.

Van den Brink, T. 2018. "National Parliaments and EU Economic Performance Policies. Impact defines involvement?" Journal of European Integration.

Van Rompuy, H., et al. 2012. The Four Presidents' Report Towards a Genuine Economic and Monetary Union. http://www.consilium.europa.eu/media/23818/134069.pdf.

Weatherhill, S. 2004. “Competence Creep and Competence Control." Yearbook of European Law 23 (1): $1-55$.

Winzen, T. 2017. Constitutional Preferences and Parliamentary Reform. Explaining National Parliaments' Adaptation to European Integration. Oxford: Oxford University Press. 